\title{
Improving the Benefit of Natural Resources Endowment to Economic Welfare in Indonesia: A Mixed-Method Analysis
}

\author{
Palupi Anggraeni ${ }^{\mathrm{a}, 1}$, Peter Daniels ${ }^{\mathrm{a}, 2}$, and Peter Davey ${ }^{\mathrm{a}, 3}$ \\ ${ }^{a}$ School of Environment and Science, Griffith University, 170 Kessels Road, Brisbane, 4111, Australia \\ E-mail: ' palupi.anggraeni@griffithuni.edu.au; ${ }^{2}$ p.daniels@griffith.edu.au; ${ }^{3}$ peter.davey@griffith.edu.au
}

\begin{abstract}
This paper analyses the relationship between natural resources endowment and economic welfare in Indonesia, and examines how to further benefit from natural resources through the factors of government institutions, industry value-added, and foreign direct investment (FDI). A sequential explanatory mixed-method design was used. It starts with a quantitative analysis using time-series data at the national level from 1990 to 2017 and continues with key-informant interviews to obtain further explanations from the quantitative analysis results. The findings show that the contribution of natural resources to economic welfare in Indonesia is positive only in the short term. It has helped build Indonesian development but has not been able to create economic welfare, especially for the local community. Improving institutional quality, primarily through environmental law enforcement, and increasing industry value-added, is important to create a bigger multiplier effect from natural resource rents that will benefit economic welfare. Nevertheless, FDI in the natural resource sector could be harmful to economic welfare; thus, it should be applied only to a capital intensive and high technology exploitation that State-owned enterprises are not capable of undertaking. This study also found that the regulation relates to natural resources revenue sharing needs to be improved, particularly in terms of the formula that use provincial boundaries for sharing distribution.
\end{abstract}

Keywords - natural resources; economic welfare; Indonesia; mixed method.

\section{INTRODUCTION}

Indonesia is blessed with natural resources and is grouped among the most resource-rich countries in the world [1]. It is richly endowed with vast reserves of coal, natural gas, and oil. These resources were vital to support Indonesian economic development, especially in President Suharto's era in New Order in 1967-1998. Moreover, the top three exports in 2017 were all-natural resource commodities, which are palm oil, natural gas, and coal [2]. However, recently Indonesia has lessened its dependency on primary exports, although these remain relatively high.

In 2005, a study predicted that Indonesia's economy would most likely remain natural resource-dependent [3]. This prediction has proved to be accurate up until today. In the year 2018, the top 10 export commodities are from natural resources, where seven are commodities from nonrenewable natural resources, and three from renewable natural resources. The value of these top ten export commodities contributes approximately one-third of the total export values to the economy[4]. The primary sectors, which rely heavily on natural resources, are the highest laborabsorbing sectors in Indonesia [5]. Recently, the government has been focusing on enhancing the non-oil and gas processing industry's performance, which sourced from natural resources such as coal-based industries, agriculturebased industries, and metal-based industries [6].

Even though natural resources are important for Indonesia, research has found that the economy has neither tracked a sustainable path nor progressed in the right direction to achieve substantial improvements in welfare related to natural resource use [7], [8]. The growth of GDP per capita in Indonesia has barely signified sustainability [9]. Furthermore, many provinces rich with natural resources are among the least-developed regions in Indonesia [10]. The Gini Coefficient-an indicator to measure the level of inequality_shows that Indonesia's inequality is among the fastest widening in East Asia. In September 2018, the Gini Coefficient was 38.4 points [11], far higher compared to 30 points in 2000 [12]. Therefore, out of the total population, $9.8 \%$, or more than 25 million Indonesians still live below the poverty line. This economic and social disparity has been led by a shift in Indonesia's leading sector of employment from agriculture to manufacturing and industrialization in some parts of the country. In contrast, other parts have been left with standard and minimum development.

To improve this situation, the Indonesian government has been moving towards a focus upon inclusive and environmentally sustainable growth, where the natural resource management sectors have received high priority 
support [13]. Research suggests that resource mismanagement in a country which caused by not saving and investing the natural resource rents is a problem for sustainability [14]. Further, the 2015 report from the Asian Development Bank (ADB) stated that sustainable growth goals would require an improvement in environmental and natural resource management.

Improving the management of natural resources requires involvement from stakeholders (such as the government, community, and investors) in many aspects, including institutions, education, investment, and others. Research suggests that complementing natural resources with good institutions is the key to social and economic success in a country [15]. The quality of institutions is a powerful factor in improving welfare [16] and in avoiding the resource curse. In this situation, generous endowments of natural resources do not seem to benefit growth in a country [17]-[20]. The institutional factor can be considered by measuring corruption, bureaucratic quality, and the rule of law [21].

The government has currently been prioritizing the reinforcement of institutions to improve the management of natural resources. However, this country may need to develop more than the institutional aspect of natural resource management to achieve the desired economic welfare outcomes. There are likely to be many other factors that interact with the process of attaining welfare from natural resources rents. A meta-analysis study found that several factors influence the estimated effect of natural resources on economic growth; these include the level of the investment and the institutional quality[22].

Previous studies relating to investment show that foreign direct investment (FDI) has a more substantial positive influence on income growth in host countries, by having a more significant impact on achieving optimum use of resources in the host country [23]. Countries that are rich in natural resources are better at fostering FDI flows because they can enhance and improve the resilience of economic growth via promoting innovation, export diversification within natural resource-based activities, and the stimulation of intra-industry trade in the region [15]. Nevertheless, a study also highlighted the fact that FDI in the sector of the natural resource may lead to indirect negative effects like environmental degradation and corruption [24]. Recently, the government has launched a policy to attract 100 percent foreign investment in some fields where Indonesia is supposed to have comparative advantages. Some of the fields are in the natural resources sector, such as oil and gas surveying and sea exploration, forestry products like plywood, and others.

The government has also launched a regulation that bans exports of certain minerals to increase the development of domestic processing facilities and become an exporter of value-added industrial products. It is to maximize the value of natural resource products and to gain as much benefit as a country can take, for example, from the manufacturing industry that may open more extensive job opportunities and can boost the economic welfare in the country. In Moldova, the research concluded that high value-added in horticultural products results in the development of the country through an increase in revenues and wages [25]. Another study found that rather than focusing on export earnings, adding value to natural resources by processing to transform into the final product is a way to achieve economic growth [26].

Based on the recent policy related to natural resources management in Indonesia and the previous studies, this research is subject to the relationship between natural resources endowment and economic welfare in Indonesia. This research examines how to improve the benefit of natural resources through the factors of government institutions, industry value added (IVA), and foreign direct investment (FDI). This current study extends the previous study done by writers that employed quantitative analysis only [27]. This recent study employs mixed-method analysis by adding qualitative analysis for the Indonesian case, to comprehend the previous quantitative analysis results, while also updating the previous data, by adding data from the year 2016-2017.

\section{MATERIALS AND METHODS}

A sequential explanatory mixed-method design was used to achieve the objectives of this study. It started with a quantitative analysis using time-series data at the national level from 1990 to 2017. The results from the quantitative analysis were then used to develop a set of questions for semi-structured interviews with key informants. The interviews resulted in a set of primary data that were analyzed further using NVivo software. The mixed-method sequence was then completed by interpreting the results from the analyses. This sequence is described in Figure 1.

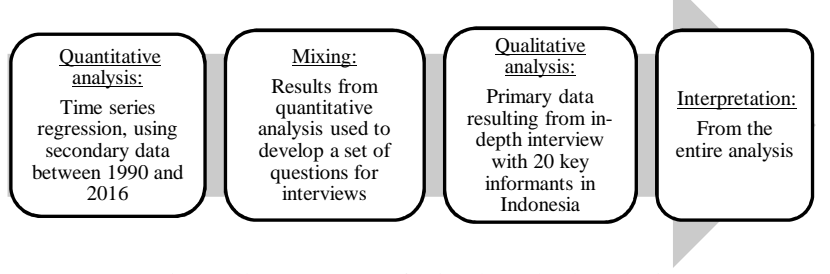

Fig. 1 The sequence of mixed-method analysis

The purpose of including both quantitative and qualitative analytic approaches was to obtain deeper and more comprehensive insights to achieve the objectives of this study. If quantitative analysis provides results based on higher-level theory and data, the qualitative analysis would complement these findings and relate the results to the real situation on the ground [28].

The relationship among factors in this study is plotted in the framework in Figure 2. As the objective of this study is to examine the relationship between natural resource endowments and economic welfare, in figure 2 , an arrow from the natural resource endowments box points to the economic welfare box. It shows that this study looks at how the natural resource endowments (as the independent variable) impact on economic welfare in Indonesia (as the dependent variable). In the bottom box are the factors that may have an impact on the relationship between natural resource endowments and economic welfare (i.e., IVA, institutional quality, and FDI). Under the institutional quality factor, six boxes represent the six dimensions of institutional quality [29]. All these factors will be examined to see how they impact on the natural resource endowments and economic welfare relationship. 


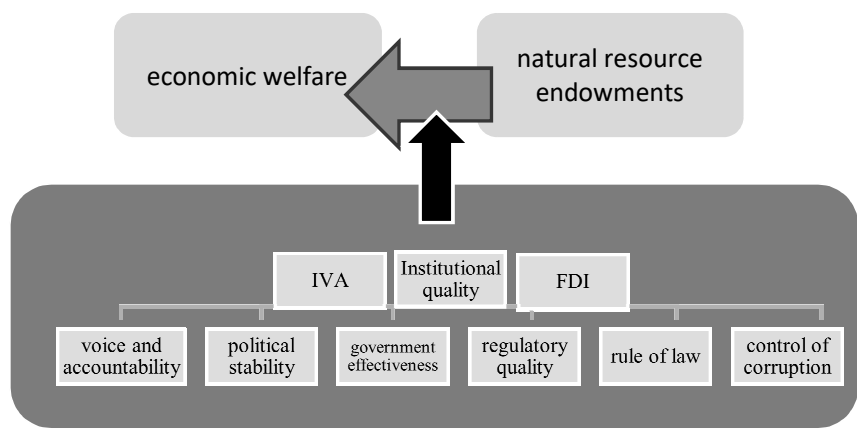

Fig. 2 The research framework

\section{A. The Quantitative Analysis Method}

The quantitative analysis for this study relied on secondary data provided by international agency bodies, including the World Bank, and the national agencies of the Government of Indonesia, i.e., the Central Bureau of Statistics, as the supporting sources. This quantitative analysis aims to examine the relationship between natural resource endowments and economic welfare, as well as the effect of the three variables of institutional quality, level of investment, and industry value added during the period from 1990 to 2018. The analysis was performed by running STATA package software, using a time series regression method.

For testing these variables, this study chose proxies that are considered best in representing the variables. The details of each variables' proxies are described below.

1) Natural resource endowments: Since this study intends to measure the contribution of the natural resource endowments to economic welfare, a total natural resource rents (as \% of GDP) indicator, published by the World Bank [29], will be used as the proxy for natural resources. The indicator sums the rent value of natural gas, oil, forest, coal, and mineral, which have been made available annually from 1996 until 2018. Natural resource rents claim to provide a much less vague measurement of resource dependence, compared with other data such as oil exports, primary commodity exports, or oil reserves. They also claim to describe the nature of a government's reliance on natural resource extraction [30].

2) Economic welfare: This study adopts an economic welfare indicator-one that has some advantages over simple GDP-based measures. The study uses Adjusted Net Saving (ANS) to include government services such as health and education for households and individuals, while also emphasizing income distribution and wealth in society. Adjusted Net Saving (ANS) measures the saving rate of a country, by taking into account the human capital investment, produced assets depreciation, and environmental degradation [31]. The ANS has a positive and significant relationship with aggregate welfare, which is measured using the Human Development Index (HDI) and the Infant Mortality Rate (IMR). The World Bank provides the data of ANS as ANS, including particulate emission damage (current USD).

3) Institutional Quality: As a measurement of institutional quality, this study employs data from the Worldwide Governance Indicator from the World Bank, which covers six dimensions of governance. The dimension was set up by utilizing a large number of assessments from surveys worldwide about perceptions of governance [32]. The original data ranges are between -2.5 to 2.5 , which represent the weak government to strong government performances. For this study, the range was changed into 0 (weak government performance) to 5 (strong government performance). Part of the data relating to institutional quality was only provided in even-numbered years in their early publication from 1996 to 2002 period. Due to this situation, this study will add the data in the missing years using the interpolation techniques.

4) Foreign Direct Investment: For the measurement of investment, this study employs World Bank net foreign direct investment (BoP, current US\$), which sums, from balance of payments, data of capital equity, earnings reinvestment, and short and long-term capital [33]. This study transformed the original data in current US\$ into per capita by calculating the population.

5) Industry Value Added: This study employs the data of industry (including construction), value added (current US\$) compiled by the World Bank. The indicator adopted includes value-added in various sectors such as mining, construction, manufacturing, electricity, gas, and water industries [34]. In this study, the original data in the current US\$ was transformed into US\$ per capita. The first model constructed in this study was developed from the main relationship where adjusted net savings (ADJNETSAV) was set up as the dependent variable, and natural resource rents (NRRENT) as the independent variable (equation 1). Since this study focused on the nature of natural resource rents, NRRENT was treated as the main independent variable included in all variants of the models analyzed.

$$
\text { ADJNETSAV }_{t}=\alpha_{n}+\beta_{n} \text { NRRENT }_{t}+\mu_{t}
$$

This model in equation 1 was then modified by adding control variables. Acting as the control variables were FDI (INVESTCAP), institutional quality [INSTIT], and IVA (VALUEADD) (equations 2, 3, and 4). As mentioned earlier, the variable of [INSTIT] consists of six dimensions [35]. Thus the model which included [INSTIT], was run six times, each with one institutional quality proxy dimension.

$$
\begin{gathered}
\text { ADJNETSAV }_{t}=\alpha_{n}+\beta_{n} \text { NRRENT }_{t}+\beta_{n} \text { INVESTCAP }_{t}+\mu_{t} \\
\text { ADJNETSAV }_{t}=\alpha_{n}+\beta_{n} \text { NRRENT }_{t}+\beta_{n}\left[\text { INSTIT }_{t}+\mu_{t}\right. \\
\text { ADJNETSAV }_{t}=\alpha_{n}+\beta_{n} \text { NRRENT }_{t}+\beta_{n} \text { VALUEADD }_{t}+\mu_{t}
\end{gathered}
$$

The models were then expanded to include a moderator variable (as in equation 5, 6, and 7). The moderator variables, analyzed in the following equations, were the independent variables. The independent variables were treated as moderator variables by adding an interaction term between the main independent variables.

In this case, the interaction effect was tested by putting an interaction term between NRRENT and INVESTCAP, NRRENT and INSTIT, or NRRENT and VALUEADD variables. This test was named Moderated Regression Analysis (MRA) — a regression-based technique that is used 
to identify the moderator variable by using an interaction term between the moderating variable and the independent variable.

A moderator variable is defined as a variable that affects the strength of the relationship between a dependent and independent variable [36], [37]. Moderator variables, if found to be significant, can cause a strengthening or weakening effect between the main independent variable (NRRENT) and dependent variable (ADJNETSAV). For example, if the interaction effect between NRRENT and $V A L U E A D D$ is found to be significant, then VALUEADD is confirmed as a moderator variable that affects the relationship between NRRENT and ADJNETSAV.

For defining whether the effect of VALUEADD is strengthening or weakening the relationship, further analysis needs to be done. Since the interaction effect in this study was tested between two continuous variables, the analysis to discover the effect of the moderator variable on the main relationship was done by plotting the values of the variables into a graph.

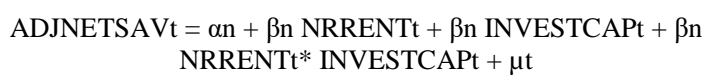

ADJNETSAV $_{\mathrm{t}}=\alpha_{\mathrm{n}}+\beta_{\mathrm{n}}$ NRRENT $_{\mathrm{t}}+\beta_{\mathrm{n}}[\text { INSTIT }]_{\mathrm{t}}+\beta_{\mathrm{n}}$ NRRENT $_{t}^{*}\left[\right.$ INSTIT $_{t}+\mu_{\mathrm{t}}$

ADJNETSAV $_{\mathrm{t}}=\alpha_{\mathrm{n}}+\beta_{\mathrm{n}}$ NRRENT $_{\mathrm{t}}+\beta_{\mathrm{n}}$ VALUEADD $_{\mathrm{t}}+\beta_{\mathrm{n}}$ NRRENT $_{\mathrm{t}}$ VALUEADD $_{\mathrm{t}}+\mu_{\mathrm{t}}$

\section{B. The Qualitative Analysis Method}

After the results from the quantitative analysis were obtained, this study applied a qualitative analysis by employing primary data drawn from a series of semistructured in-depth interviews to gather facts and opinions. To gather this data, a list of questions was asked to several experts or key informants in the natural resource sector. Thus this kind of interview is called a key informant interview.

Key informant interviews are a research method where an expert source of information is utilized. The informants are experts because of their particular skills, experience, or relevance of their position within organizations or society [38], and they are selected on the basis that they are likely to provide the required information, ideas, and insights on a particular subject. Taking advantage of the knowledge that the informants have, a semi-structured interview with openended questions will be completed. This interview technique requires the researcher to have prepared several questions in advance, with the questions being adequately open so that the subsequent questions can be improvised [39]. It allows the researcher to vary the questions to draw participants' attention to the topic completely [40].

Twenty key informants representing the government and non-government sectors were interviewed. There were six groups of informants representing policymakers, researchers, executives, academics, activists, and experts from international organizations (Figure 3 ). These six groups were chosen to involve all the parties that: are relevant in the decision making process and its implementations (policymakers and executives); have expert knowledge in the research focus area (researchers, academics); and know the real situation on the ground (natural resource sector NGO). The interviews were conducted face to face and audio recorded. The audio was then transcribed, and the analysis was conducted by using NVivo 12 software.

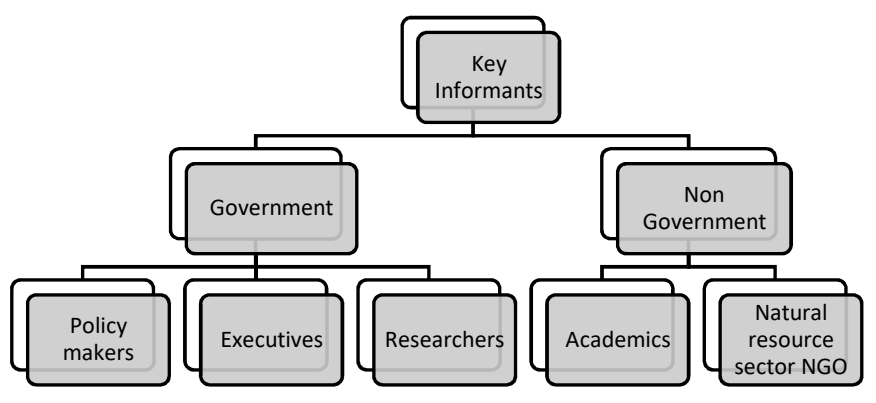

Fig. 3 The group of key informants

\section{RESULT AND DISCUSSION}

\section{A. The Quantitative Analysis Results}

The results from the quantitative analysis show that the rents generated from natural resource sectors have an ambiguous association with economic welfare. Most of the results show there is no association between natural resource rents and economic welfare, while a few show negative associations.

When FDI, IVA, and institutional quality were treated as independent variables in the models, the results show that these three variables have a significant effect on economic welfare. The coefficient of the IVA and institutional quality variables are positive, which means that industry valueadded, as well as the institutional quality variables, have a direct positive effect on economic welfare. Therefore, when there is an improvement in the quality of institutions, it may increase the level of economic welfare in Indonesia. The same condition applies to industry value-added, where an increase in the industry value added may increase economic welfare.

FDI, based on its coefficient, has a negative effect on economic welfare. This means that an injection of funds in terms of FDI may need to be reduced to increase economic welfare. This study finds that none of the moderator variables tested has a significant interaction effect that can improve or weaken the relationship between natural resource rents and economic welfare.

\section{B. The Qualitative Analysis Results}

The Indonesian government, as was said, has been moving towards a focus upon inclusive and environmentally sustainable growth, where natural resource management sectors have received high priority support [13]. Nevertheless, the exploitation of natural resources in Indonesia is mostly attributed to the practice of ignoring environmental rules and cultural practices [41]. The exploitation exists because the management of these assets has been seen in a developmentalism perspective, which sees natural resources as an object to achieve economic development [42]. Thus, natural resources management in Indonesia needs to be improved, as the interviewees of this study have recognized. Natural resources need to be perceived for their ecological and sustainability value rather than economic value [43]. 
Several issues related to natural resource endowments and economic welfare were discussed in the interviews. One of these relates to resource exploitation practice, with the State being given the authority as the regulator, and corporation as the executor in the field. Nevertheless, the executor privilege to explore and exploit natural resources is likely occupied by a corporation owned by certain elite groups of people [44]. These elites have more prominent entry points to the natural resources exploitation opportunities since they had good access to State apparatus, which makes it easier to acquire the licenses and contracts that could magnify their business [45].

The natural resources in Indonesia are perceived as transactional assets, where access is limited to the big companies or elite groups in Jakarta and even abroad (Interview, NGO activist, 2018).

This exploitation, which mostly benefits the elites, impacts negatively on the local community. As in situ actors, the community is marginalized in natural resources management because two other actors, i.e., government and corporation, have taken its place [42]. Moreover, exploitation of natural resources tends to severely affect communities that are highly dependent on their environment, causing a loss of the potential benefit of natural resources [46]. This has happened from a shift in the area use from agriculture into mining. In contrast, the indigenous community has been pushed aside by the newcomer that has higher education and skill levels. One study mentioned this situation as diminishing the welfare that the local people used to have when they worked as farmers [47]. One government official, when asked about how natural resource endowment impacted upon the welfare of the community, made an example of forest exploitation practice:

The local community who live close to the forest, mostly rely on the woodland for a living. When a forest turns into a production forest, the access of the people will be cut out. For example, some of these people usually can look for honey or firewood from inside the forest and sell it in the market, but now they cannot. This situation reduces the income of these people. Thus it can be seen that the exploitation of a forest reduces the welfare of the local community.

(Interview, government official, 2018)

Natural resource exploitation, when performed by depleting natural capital, can lead to higher economic growth. Nevertheless, the growth can only be sustained if the revenues from resource extraction created an accumulation of other assets, such as human and physical capital. This is important to protect future development when natural capital has been exhausted [48]. Some of the interviewees mentioned that natural resources contribute to economic development only but failed to provide creating welfare for the community.

The rents from natural resources exploitation contribute to the macroeconomic outlook of this country; meanwhile, society suffers because their land is destroyed due to environmental degradation (Interview, NGO activist, 2018).

The tremendous economic development in Indonesia, particularly during the New Order-President Suharto era, is indeed sourced from natural resource rents. Thus, the resources have contributed to short term development for Indonesia. However, the poverty level that mostly occurs close to the natural resource exploitation area and various environmental issues related to environmental degradation shows that development sustainability has been ignored.

The contribution of natural resources is positive in the short term, for example, through the royalties gained from minerals exploitation. Nevertheless, this benefit hardly ever trickles down to the community in the area. (Interview, researcher, 2018)

The initiation of a natural resource revenue sharing formula was designed to distribute the rents generated from the natural resource sector to each region, with a producing region having a bigger share. The resource-rich provinces can then have bigger fiscal capacity that can be utilized for a poverty reduction program, public service improvements, and other welfare-oriented activities [47]. As the prologue of Law 25/1999 on Fiscal Balancing between the Central Government and Regional Government, this aims to improve social welfare and create a condition that free of corruption, collusion, and nepotism in civil society [49]. Nevertheless, poverty mostly occurs in the circle closest to the mining area. This has happened because the mining operation shifted agricultural land into mining exploration [47], which led to a change in the community's work from farming to mining.

This research concerns on five sub-provinces producing oil and gas and mining resources in Indonesia. A study found that budget allocation for social security, which is the main instrument in poverty alleviation, is very small, with the social security budget varying from 0.79 to 2.29 per cent of the total budget [47]. Scholars have argued that social security is the instrument that can impact directly on the poorest [50], [51], while development on human and physical capital can only be effective over the longer term, and that the impact of this development hardly touches lowincome people [47].

To assure that the revenue from natural resources brings impact to the local community, a law that mandates the allocation of natural resource revenue sharing needs to be made. There are at least three points that need to be considered when making the regulation. First, the allocation should mandate a certain minimum percentage of the total revenue sharing to certain activities, such as the social security budget, that can have a direct effect on the people close to the exploitation in the region. The objective is to make sure that the revenue from natural resources benefits the poorest. Second, the natural resource revenue sharing should also mandate a certain minimum percentage of the total revenue sharing allocated to conservation programs in the exploitation area. It can help minimize environmental degradation in the impacted area. Third, the revenue sharing allocation should be distributed to people in the circle closest to the exploitation area, without limiting the area based on provincial boundaries.

Today's regulation of natural resource revenue sharing was made based on principles of 'by origin', with provincial boundaries. This principle states that a producing region gets a certain allocation. In contrast, other non-producing regions in the same province receive the same total amount, but this total is divided equally among these non-producing regions. Meanwhile, the exploitation circle area may cover several sub-provinces in more than one province. It will create a gap for the people in the closest circle who live in different 
provinces since they are considered as a non-producing region which receives a minimum or no sharing allocation. An interviewee mentioned this:

The policymaker who makes the natural resource revenue sharing regulation should be aware that the impact of exploitation, such as environmental degradation, may reach not only the producing district. Sometimes the externalities are borne by the producing district and its neighboring district which may belong to different provinces. These neighboring provinces, the impacted district, should receive an allocation of the revenue sharing as the region in the circle closest to the exploitation area (Interview, academic, 2018).

Resources exploitation in Indonesia, as in many developing resource-rich countries in the world, was driven by foreign investments [52]. FDI is projected to deliver a significant role to development through assets transfer, as well as technology and managerial skills that can advance growth in the economy [53]. Research relating to FDI in Indonesia seems to have mixed results; among these is a study that found FDI does not have any impact on GDP [54], another found negative results [53], and another found positive results [55]. The examples of FDI reliance for natural resources exploitation exist in the palm oil sector [56, 57], oil and mining sectors [58], and forest sector [41].

Nevertheless, the interviewees stated that FDI in the natural resources sector generally favors only an exclusive group of people. FDI inflow may create new job opportunities, but the people who can get these jobs majorities come from a highly-educated background or are highly-skilled labor, and therefore are not likely to come from the local community. One study mentioned that a multi-national company-which FDI in Indonesia has likely transformed-reserves lead managerial positions for their preferable managers who may conduct strategies based on MNC's benefits at the cost of local social welfare [59].

According to the Government Regulation 47/2012 about social and environmental responsibilities, all companies must allocate an operational budget as a form of responsibility for any social and environmental impact. This practice is usually called a corporate social responsibility (CSR). Hence, Du and Vieira [60] argued that multi-national companies tend to implement several strategies in undertaking CSR activities just to get legitimacy. The political power structure and bureaucratic practices in Indonesia are arbitrary, which allows MNCs to take steps that allow collusion with opportunist politicians and bureaucrats [61], thus providing incentives for corruption [62]. An interviewee mentioned that CSR tends to be used for activities that hardly impact on local communities.

The amount from CSR, even when it works, is very small and incomparable to the loss caused by resource-exploitation. In fact, CSR tends to be used by companies to cooperate with the ruling apparatus. For example, regional election billboards sometimes are filled with the names of the candidate, who are usually elected and who are re-applying for their second election, and a name of the palm oil company (Interview, NGO, 2018).

The reason why CSR does not really benefit the local communities may come from a lack of control and capability in negotiating favorable terms by the government. Research has stated that poor negotiating capability may lead to a bigger return and benefit for the MNC compare to the government of Indonesia [63]. This is compounded by the fact that in low-development countries, labor usually less organized and has no bargaining position to negotiate, therefore becomes a victim of human exploitation [61].

Most MNCs in Indonesia is operating in the natural resources sector. However, the economic growth created from the industrialization and natural resources exploitation by MNCs is very vulnerable [61]. This is because the whole production processes are controlled, dominated, and dependent on their home company. Moreover, the key components usually must be purchased or supplied from home firms. The research concluded that MNCs in Indonesia create development-reliance, limited technology transfer, labor exploitation, encourage collusive government practices, and natural degradation [61].

The government seemed aware of this situation, so regulation was launched to push oil and gas companies to use more local goods and service providers, and restrict the usage of foreign employees [45]. This regulation seemed to be able to recover the situation and advantage of local people. However, resources activists see this rule as a benefit only on paper. Even though the FDI inflow may bring a multiplier effect to the local economy by increasing demand for local services it basically provides material things as a replacement for the access to natural assets.

Land clearing for production forest or mining business pushed the local people away from their work as farmers and made them depend on the work created by the exploitation business (Interview, NGO activist, 2018).

As a solution, one interviewee stated that the government needs to limit the injection of funds to high technology and capital-intensive exploitation and slowly lessen the reliance on foreign direct investment in the natural resource sector.

The government needs to carefully select categories of natural resources that need to have foreign investment for their exploitation. This selection needs to consider the capabilities of state-owned companies or local private companies and prioritize domestic rather than foreign interests (Interview, researcher, 2018).

Recently, with Presidential Regulation 44/2016, the government has attracted 100 per cent foreign investment in some fields, including the natural resources sector. This includes oil, gas, geothermal energy and forestry. For oil, gas and geothermal energy, the investment was encouraged for a survey, drilling, construction, operation, and maintenance [64]. Hence, there is a possibility that this regulation creates a similar trap for Indonesia, that is, to boost development at the surface level while ignoring the welfare of the local community. Thus, careful consideration should be taken by considering the potential of state-owned enterprises and domestic private companies.

Institutions hold an important role in ensuring that rents from natural resource exploitation can be transformed into economic welfare. Even though scholars tend to categorized Indonesia as a state with medium-strong to strong level in terms of designing policy and supervising private companies, research has argued that this classification should be done cautiously, by considering characteristics of the specific sector [41]. 
One study argued that Indonesia has insufficient institutional resources, poor policies, and pervasive patronclient joins among state authorities and natural resource exploration companies [41]. Further research mentioned that in the natural resources sector, regulation in Indonesia is not transparent, and the institutions are ambiguous [45]. The special characteristics of Indonesia's natural resources, such as isolated location with minimum access, together with poor institutions, raises many challenges in natural resource management [48].

Improvement in natural resource management, particularly related to institutional quality, needs good accountability or clarity in defining the role of each ministry or agency. The change of the role of ministries responsible for natural resource management likely happened due to the change of the political strategy impacted from the change of President. An example is in forest management, as mentioned by an interviewee. Originally, there were two ministries responsible for forest management, i.e., Ministry of Forestry and Ministry of Environment. These two ministries merged after 2014 when Jokowi became the President. Nevertheless, the merger led to some confusion in the work-sharing and responsibilities and caused some significant tasks at the bottom level to remain untouched.

When the Ministry of Environment and Ministry of Forestry were merged, there was a new general directorate named Law Enforcement which is positioned at the national level. Before, the responsibility was owned by the regional level or smaller, which was located closer to the forest. Due to this change, whenever there is an issue, the unit close to the forest cannot settle the problem directly since it has no authority (Interview, NGO, 2018).

Based on the above discussion, this research rechecked the structure and function of this office. According to the productivity report by the Law Enforcement General Directorate in 2017, there are five vertical offices (Balai Pencegahan dan Penegakan Hukum Lingkungan Hidup) to protect the national forest assets all over Indonesia. Each office is responsible for one or a few big islands, which is a vast area to cover. Even though the Minister of Environmental and Forestry Regulation in 2018 mandates that prevention and forest protection can be executed by a forest area manager and forest utilization permit holder, in the field the execution is still far from ideal [65]. The report also mentioned that the number of functional staff that can supervise and resolve problems in the field is very limited. Meanwhile, forest protection needs many human resources, as well as facilities and big budgets. Thus activities to prevent law violation in the forest are still focused in several areas that have high-level insecurity [66].

Another dimension of a quality institution that needs to be improved is the regulatory quality. One study stated that the Indonesian mining sector is characterized by regulatory ambiguity, as policies are frequently retracted, revised, and sometimes revived [67]. Research by the Fraser Institute in 2018 found that oil and gas regulation in Indonesia is easily changed thus reducing the interests of investors [68]. The Corruption Eradication Commission states that poor quality of regulation in the natural resources sector not only perpetuates corruption practice and creates country loss, but also natural resources access injustice and environmental degradation, which mean public rights were violated.[69].

Poor regulatory quality can appear in terms of an overlapped regulation. Regulation in the natural resource sector has many problems due to misrepresentation or overlapping laws. This has happened because these regulations cover different interests [69]. One interviewee gave an example in the forestry sector:

Several regulations have parts that overlap with others, for example, between agrarian principal law and forestry law specifically in terms of customary land articles (Interview, government official, 2018).

Several actions have been taken to improve the quality of regulations in the natural resource sector. One of the recent steps is the harmonization study of national resources legislation. The study analyzed twenty-six regulations in the natural sector to identify regulation problems that cause corruption, and economic and social disparity. The aim was to ensure that regulations and policies in the natural resource sector achieve their constitutional objectives [69].

Control of corruption, which is one of the institutional quality dimensions, needs to be improved, as mentioned in the interviews. A form of corruption can come as a permit handed to private entrepreneurs or companies, without good supervision. Another form of corruption can relate to government effectiveness. For example, various policies launched from both the central and local governments tend to marginalize people who have rights over the area. These policies are taken because the ruling apparatus wants to get benefits for themselves.

An apparatus which has power in the local government tends to make decisions that benefit its own interest (Interview, NGO activist, 2018).

One scholar equates the corruption practice in Indonesia with the democratic type-political situation in Indonesia. The research states that the poor practice in institutions was driven by Indonesia's expensive democracy, where an apparatus, as a representation from a political party, seeks help from wealthy businesspeople to finance election campaigns, party events, and raise funds for building political coalitions [45].

Other than these dimensions of institutional quality, another important dimension appears in discussion with the interviewees. Several key informants mentioned that many actions had been done to improve the quality of institutions in Indonesia. However, they have not brought satisfactory results. Thus, several interviewees argued that leadership is important in improving institutional quality in the natural resource sector. One interviewee made an example of how leadership practice can help build the institutions.

Instead of spending all the revenue received from natural resources extraction to cover development costs in his region, a leader made a perpetual fund to save some part of the revenue from the natural resources sector. The fund functioned like a savings account to anticipate whenever natural resources were exhausted and could not be used to provide funds to rebuild the ecosystem (Interview, academic, 2018).

Value added is important for a country's growth. It creates extra resources for the country, enables higher living standards [55], increases innovation and provides more jobs 
[70]. The government, alongside many Indonesian experts, stated that it is vital for Indonesia to become a value-added resource economy. This economy requires companies to invest in downstream facilities and process their raw commodities domestically prior to export. Among the strategies of the Ministry of Industry to build a national industry that has high competitiveness in the global level are developing natural resource-based upstream and midstream industries and controlling raw commodities' export [71].

One of Indonesia's problem is its low position in the global value chain. The common situation is that Indonesia's resources are exported to other nations, being processed into other products, and later imported back to Indonesia [72]. One example of this situation exists in the nickel industry. Although processed ferronickel is heavily needed at local industries such as construction, automotive, electronics, and train rail industry, unprocessed ore nickel exports are at a maximum level[71].

This situation is like the dependency theory by Raul Prebisch. According to Ferraro [73], the theory argued that the increase in the wealth of the richer nations appeared to be at the expense of the poorer ones. The research by Ferraro [73] further stated that foreign companies dominated resource industries in poor countries, so the poor countries are pushed to sell cheap primary commodities to advanced industrialized countries.

In terms of industry value-added, interviewees highlighted the importance of processing the raw materials from natural resource exploitation into intermediate or final products that have more value. The objective is to push the advancement of a downstream processing industry that can improve Indonesia's position in the global value chain. This can be achieved by producing higher-value products instead of cheaper ones.

The government needs to take examples from other countries such as South Korea, in terms of how the country bans their natural resources for trading or exporting if the materials have not passed through a processing phase (Interview, academics, 2018).

Several policies have been developed to increase the value-added industry. Some examples include a ban on mineral ore exports, an onerous tax on unprocessed copper exports, and pressure on companies to build smelters. In 2009, the government-mandated a new Mining Act where more minerals produced in Indonesia have to be processed domestically. This includes copper, nickel, bauxite and iron ore. In 2012, the government required that the mining sector should be majority-owned by Indonesian within the next ten years. The government also forced a $20 \%$ export tariff on exports of raw minerals, and licenses are only available to companies which commit to building smelters in Indonesia to process their minerals. Lastly, from 2014, the government started a total ban on the export of unprocessed minerals [74]. The policy had begun to show results with downstream investment being injected into smelting facilities for mining industries [67].

The strategy (to push companies to build smelters) is finally being executed. Nevertheless, the government needs to ensure that the implementation will succeed through control and monitoring (Interview, academics, 2018).
The above statement about ensuring the implementation of the value-added supporting policy should be highlighted. The government is likely to revisit its own policy. For example, in 2017, the government relaxed 2014 [45], [75]. The relaxation applies for five years or until 2022. Yet, recently there is a discourse to bring the export ban forward to 2021 [76]. This delayed implementation of the government's own regulation likely happened because of political and economic trade-offs. On the one hand, the smelter facilities are still not ready for operation, while the demand for mineral export remains high. On the other hand, Indonesia must do the processing and purification domestically as the Law 4/2009 about Minerals and Coal Mining mandated. The trade war between the USA and China has played a role in influencing the government's decision to implement a raw minerals export ban to increase the export of processed minerals [77]. Despite the pros and cons of the government's ambiguous action on the raw minerals export ban, the expert stated that the current government is committed to developing a domestically owned and value-added natural resources sector [45].

\section{Discussion}

The quantitative analysis results show that it is hard to determine the role of natural resource rents on economic welfare in Indonesia due to the inconsistency of the coefficient signs in each of the equation's results. The coefficients of natural resources endowment are not consistently positive, or consistently negative. This means the results are not robust and cannot be used to conclude that the rent generated from natural resources in Indonesia has contributed to its economic welfare. This finding is supported by the qualitative analysis results where the interviewees argue that the contribution of natural resources was very beneficial in supporting Indonesian development, yet could not create economic welfare, especially for the local community. Further, the exploitation of the natural resources was not sustainable and in the long term could destroy the economic welfare.

From the three factors put into the models, foreign direct investment as a moderator variable does not have significant results in the natural resource endowments-economic welfare relationship. The qualitative analysis results also support this, namely where interviewees argue that FDI in the natural resources sector should be applied only to a capital intensive and high technology exploitation that the State-owned enterprises cannot undertake. Another study mentioned a similar, yet different suggestion. Instead of limiting the application of FDI on a very specific natural resources sector, this study suggests that low- and middleincome countries should attract FDI into the non-resources sector [78].

The reason a country needs to be cautious with a fund injection in terms of FDI is due to the nature of foreign investment where every investment is a business, so the investors want to ensure they will obtain profits and benefits. Hence, the contract that regulates natural resource exploitation tends to provide more benefit to the investors rather than to the Indonesian government. For example, the benefit-sharing clause in the investment contract seems to give fair benefit to each party, but in reality, the local 
community almost always suffers a negative impact from the exploitation, which is never measured by the government. External assistance in negotiating and renegotiating FDI contracts in the Indonesian case may be needed, provided by some multilateral financial institutions that can help settle disputes and ensure contract stability [79].

One study states that the main motives for a country to practice FDI is to seek a market, resources/assets, and efficiency [80]. This is in part a good opportunity for the host country, because it may open new employment opportunities or provide potential new revenue. Still, on the other hand, it may bring some problems too. A real example from another study also showed that Chinese FDI is motivated by self-interest and can be highly detrimental to the development prospects of host countries [81]. Thus, a balanced, fair proportion share of extractive industry payments to be given to local communities needs to be carefully addressed [79].

This study found that strengthening the quality of institutions and pushing the creation of industry value-added should be the two foci if the government wants to guarantee that rent generated from the natural resource sector contributes to economic welfare. Institutional quality should be related to accountability, the rule of law, control of corruption, and regulatory quality specifically about contract transparency. This last strategy about improving the quality of contract enforcement was the most frequent issue in the interview. Several interviewees mentioned that the government needs to position itself as the party with a higher bargaining position during the negotiation of contract formulation and not be afraid to terminate the contract along the way if the investors failed or displayed poor behavior related to contract compliance.

Regarding the creation of industry value-added, the government's current policy about adding value to industry products needs to be maintained and improved since this has a significant positive impact on the contribution of natural resource rents to economic welfare. Indonesian exports currently still rely on commodities sourced from raw materials or primary ingredients. Thus, the net export-import trade balance is heavily affected by the fluctuation of commodity prices. Enhancing industry value added for export products will create a stronger trade balance.

This study also found that the regulation that relates to natural resources revenue sharing needs to be improved, especially in terms of the allocation of the revenue sharing in the regional budget. Currently, natural resource revenue sharing is pooled in a regional budget. The decision for budget allocation is then discussed among the regional government and the Regional House of People's Representatives (or DPRD) [82]. This discussion creates a potential that the natural resource revenue sharing might be utilized for other purposes which are unrelated to the natural resource management, or not necessarily of benefit to the quality of life of people in the exploitation area. A regulation mandates the use of this sharing is available only for reforestation fund. This fund can be used only for forest and land rehabilitation and other supporting activities like prevention of forest fire and tree planting.

This study suggests that new regulations should be made to mandate the natural resource revenue allocation for natural resource conservation and poverty alleviation activities that focus on societies closest to the resource exploitation area. An improvement in the natural resource revenue sharing formula is also needed so it may consider a bigger proportion for the region at the circle closest to the exploitation area.

\section{CONCLUSIONS}

Even though Indonesia is a resource-rich country which, in some phases of its development, heavily relied on natural resources, this study found that the natural resource endowment has helped build economic development but has not created economic welfare. This research focused on how to improve the benefit of natural resources endowment for economic welfare in Indonesia. This research found that strengthening the quality of institutions and pushing the creation of industry value-added should be the two foci if the government wants to guarantee that the rent generated from the natural resource sector contributes to economic welfare. Even though the government has been applying these two factors in natural resource management, the implementation still does not meet expectations. Concerning foreign direct investment in the natural resource sector, the government needs to limit the injection of funds to high technology and capital intensive exploitation. It needs to slowly lessen the reliance on foreign direct investment in the natural resource sector.

\section{REFERENCES}

[1] Ghura, D. and C. Pattillo, Macroeconomic policy frameworks for resource-rich developing countries. International Monetary Fund, Washington, DC, 2012.

[2] WITS. Indonesia Trade at a Glance: Most Recent Values. 2017 [cited 2019; Available from: https://wits.worldbank.org/countrysnapshot/en/IDN/textview.

[3] Resosudarmo, B.P., The Politics and economics of Indonesia's natural resources. 2005, Singapore: Institute of Southeast Asian Studies.

[4] Ministry of Trade. Export Growth (HS 6 Digits) Period: 2014-2019. 2019; Available from: https://www.kemendag.go.id/en/economicprofile/indonesia-export-import/export-growth-hs-6-digits.

[5] The House of Representatives of Indonesia, Manufacturing Industry in Indonesia: Challenges and Policy, B. APBN, Editor. 2015: Jakarta.

[6] Ministry of Industry, With 18 Percent, Non-Oil and Gas Industry Becomes the Largest Economic Contributors. 2019: Jakarta.

[7] Alisjahbana, A.S. and A.A. Yusuf, Assessing Indonesia's Sustainable Development: Long-Run Trend, Impact of the Crisis, and Adjustment during the Recovery Period. ASEAN Economic Bulletin, 2004. 21(3): p. 290-307.

[8] Mollin, J. REDD+ can "green" Indonesia's resource-dependent economy, U.N. expert says. 2014.

[9] Kurniawan, R. and S. Managi, Economic Growth and Sustainable Development in Indonesia: An Assessment. Bulletin of Indonesian Economic Studies, 2018. 54(3): p. 339-361.

[10] NRGI, Subnational Revenue Distribution: Natural resource revenues in a decentralised context. 2015. March 2015.

[11] BPS. Gini Ratio September 2018 tercatat sebesar 0,384. 2019 [cited 2019; Available from: https://www.bps.go.id/pressrelease/2019/01/15/1548/gini-ratioseptember-2018-tercatat-sebesar-0-384.html.

[12] World Bank, Indonesia's Rising Divide, in World Bank, Jakarta. 2016. p. 7.

[13] ADB. Indonesia: Interim Country Partnership Strategy (2015). 2015; Available from: http://www.adb.org/documents/indonesia-interimcountry-partnership-strategy-2015.

[14] Atkinson, G. and K. Hamilton, Savings, Growth and the Resource Curse Hypothesis. World Development, 2003. 31(11): p. 1793-1807.

[15] de Ferranti, D., et al., From Natural Resources to the Knowledge Economy: Trade and Job Quality. World Bank Latin American and 
Caribbean studies - Viewpoints; Washington, DC: World Bank. (C) World Bank, 2002.

[16] Brunnschweiler, C.N., Cursing the Blessings? Natural Resource Abundance, Institutions, and Economic Growth. World Development, 2008. 36(3): p. 399-419.

[17] Arezki, R. and F. van der Ploeg, Trade policies, institutions and the natural resource curse. Applied Economics Letters, 2010. 17(15): p. 1443-1451.

[18] Bulte, E.H., R. Damania, and R. Deacon, Resource Abundance, Poverty and Development. 2003.

[19] Collier, P. and B. Goderis, Commodity prices and growth: An empirical investigation. European Economic Review, 2012. 56(6): p. 1241-1260.

[20] Mehlum, H., K. Moene, and R. Torvik, Cursed by Resources or Institutions? World Economy, 2006. 29(8): p. 1117-1131.

[21] Dietz, S., E. Neumayer, and I. De Soysa, Corruption, the resource curse and genuine saving. Environment and Development Economics, 2007. 12(1): p. 33-53.

[22] Havranek, T., R. Horvath, and A. Zeynalov, Natural Resources and Economic Growth: A Meta-Analysis. World Development, 2016. 88: p. 134-151.

[23] OECD, Foreign Direct Investment for Development. 2002, OECD Paris.

[24] Bunte, J.B., et al., Natural resource sector FDI, government policy, and economic growth: Quasi-experimental evidence from Liberia. World Development, 2018. 107: p. 151-162.

[25] Golban, A., The Increasing Of Competitiveness Of High Value Added Horticultural Production In The Context Of The Economic Growth Of The Republic Of Moldova. Scientific Papers Series : Management, 2014. 14(2): p. 133-140.

[26] Fakoya, M.B., Natural resource, value added and economic growth: Empirical analysis from selected african countries. Journal of Human Ecology, 2014. 48(2): p. 227-233.

[27] Anggraeni, P., P. Daniels, and P. Davey, The Contribution of Natural Resources on Economic Welfare In Indonesia. The Indonesian Journal of Development Planning, 2017. 1(3): p. 210-223.

[28] Bryman, A. and E. Bell, Business research methods. Vol. 3rd. 2011, Oxford: Oxford University Press.

[29] World Bank. Total natural resources rents (\% of GDP). 2018 [cited 2018; Available from: https://data.worldbank.org/indicator/NY.GDP.TOTL.RT.ZS.

[30] De Soysa, I. and E. Neumayer, Resource Wealth and the Risk of Civil War Onset: Results from a New Dataset of Natural Resource Rents, 1970-1999. Conflict Management and Peace Science, 2007. 24(3): p. 201-218.

[31] Hess, P., Determinants of the adjusted net saving rate in developing economies. International Review of Applied Economics, 2010. 24(5): p. 591-608.

[32] Kaufmann, D., A. Kraay, and M. Mastruzzi, Governance Matters VIII: Aggregate and Individual Governance Indicators 1996-2008. Policy Research Working Paper, 2009. WPS 4978(World Bank, Washington, DC. (C) World Bank).

[33] World Bank. Foreign direct investment, net (BoP, current US\$). 2019; Available from: https://data.worldbank.org/indicator/BN.KLT.DINV.CD

[34] World Bank. Industry (including construction), value added (current US\$). 2019; Available from: https://data.worldbank.org/indicator/NV.IND.TOTL.CD

[35] Kaufmann, D., A. Kraay, and M. Mastruzzi, The worldwide governance indicators: methodology and analytical issues. Hague Journal on the Rule of Law, 2011. 3(2): p. 220-246.

[36] Baron, R.M. and D.A. Kenny, The moderator-mediator variable distinction in social psychological research: Conceptual, strategic, and statistical considerations. Journal of personality and social psychology, 1986. 51(6): p. 1173

[37] Namazi, M. and N.-R. Namazi, Conceptual analysis of moderator and mediator variables in business research. Procedia Economics and Finance, 2016. 36: p. 540-554.

[38] Marshall, M.N., The Key Informant Technique. Family Practice, 1996. 13 No. 1.

[39] Wengraf, T., Qualitative research interviewing: biographic narrative and semi-structured methods. 2001, London: SAGE.

[40] Galletta, A. and W.E. Cross, Mastering the Semi-Structured Interview and Beyond : From Research Design to Analysis and Publication. 2013, New York: NYU Press.

[41] Dauvergne, P., Weak states and the environment in Indonesia and the Solomon Islands. Resource Management in Asia Pacific, 1997. 10.
[42] Jati, W.R., Manajemen tata kelola sumber daya alam berbasis paradigma ekologi politik. Politika: Jurnal Ilmu Politik, 2013. 3(2): p. 98-111.

[43] Agoes, R.E., Hukum Sumberdaya Alama: Perlukah Suatu Pengaturan Tersendiri (Suatu Kajian Komparatif). Sosiohumaniora, 2000. 2(2): p. 26-38.

[44] Varkkey, H., Patronage politics and natural resources: a historical case study of Malaysia and Singapore. Asian Profile, 2013. 41(4): p. 319-330.

[45] Warburton, E. Resource nationalism in post-boom Indonesia: The new normal? 2017; Available from: https://www.lowyinstitute.org/publications/resource-nationalismpost-boom-indonesia-new-normal.

[46] Vania Rugebregt, R., A. Saleng, and F. Patittingi, Government Policy in the Natural Resource Management of Local Community. Hasanuddin Law Review, 2016. 1: p. 122.

[47] Saputra, W. and M. Lumbantoruan, Efektivitas Pengelolaan Dana Bagi Hasil Sumberdaya Alam (DBH-SDA) bagi Penanggulangan Kemiskinan Studi Kasus Lapangan Pada Lima Kabupaten di Indonesia. 2017, Publish What You Pay Indonesia Jakarta.

[48] Dutu, R., Making the Most of Natural Resources in Indonesia, in OECD Economics Department Working Papers. 2015, OECD Publishing: Paris. p. 7.

[49] Fox, J.J., D.S. Adhuri, and I.A.P. Resosudarmo, Unfinished edifice or Pandora's box? Decentralisation and resource management in Indonesia. The politics and economics of Indonesia's Natural Resources, 2005: p. 92-108.

[50] Engelhardt, G.V. and J. Gruber, Social security and the evolution of elderly poverty. 2004, National Bureau of Economic Research.

[51] van der Berg, S. and C. Bredenkamp, Devising social security interventions for maximum poverty impact. Social Dynamics, 2002. 28(2): p. 39-68.

[52] Melina, G., S.-C.S. Yang, and L.-F. Zanna, Debt sustainability, public investment, and natural resources in developing countries: The DIGNAR model. Economic Modelling, 2016. 52: p. 630-649.

[53] Kholis, M., Dampak foreign direct investment terhadap pertumbuhan ekonomi Indonesia; Studi makroekonomi dengan penerapan data panel. Jurnal Organisasi dan Manajemen, 2012. 8(2): p. 111-120.

[54] Haris, S. and N. Danila, FDI On Economics Growth; Indonesia Case Study. Management and Economics Journal (MEC-J), 2018: p. 177.

[55] Sjöholm , F., Foreign Direct Investment and Value Added in Indonesia in IFN Working Paper. 2016, Research Institute of Industrial Economics.

[56] Johnson, T., Palm oil companies exploit Indonesia's people - and its corrupt political machine, in The Guardian. 2015.

[57] Vidal, J., Indonesia is seeing a new corporate colonialism, in The Guardian. 2013.

[58] Bresnan, J., Indonesia: The Great Transition. 2005, Rowman \& Littlefield Publishers.

[59] Adams, D., et al., Globalisation, governance, accountability and the natural resource 'curse': Implications for socio-economic growth of oil-rich developing countries. Resources Policy, 2019. 61: p. 128-140.

[60] Du, S. and E.T. Vieira, Striving for legitimacy through corporate social responsibility: Insights from oil companies. Journal of business ethics, 2012. 110(4): p. 413-427.

[61] Sampurna, R.H., A Critical Review Of The Impact of Multi-National Corporations (MNCS) on Indonesian Economy. JISPO: Jurnal Ilmu Sosial dan Ilmu Politik, 2019. 9(1): p. 221-233.

[62] Seda, F., Petroleum Paradox: The Politics of Oil and GasSome Preliminary Thoughts on Paradoxical Social Change. Jurnal Studi Amerika, 2005. X No. 1(January - June 2005): p. 55-63.

[63] Fauzi, D.T. and D.A. Mudji, Kontribusi Perusahaan MNCs Sektor Perminyakan Terhadap Perekonomian Indonesia. Westphalia, 2014. 13(1): p. 165-174

[64] Noor, A.F., Ini Daftar Bidang Usaha yang Bisa 100 Persen Dimiliki Asing, in Republika.co.id. 2018.

[65] "Pengawasan". Pengawasan dan Penegakan Hukum Lingkungan Perlu Diperkuat. 2015 [cited 2019; Available from: https://www.hukumonline.com/berita/baca/lt55376af81f311/pengawa san-dan-penegakan-hukum-lingkungan-perlu-diperkuat/.

[66] Ditjen PHLK, G.D.o.E.a.F.L.E., Laporan Pertanggungjawaban 2016. 2017

[67] Warburton, E., Nationalism, developmentalism and politics in Indonesia's mining sector. Indonesia in the New World: Globalisation, Nationalism and Sovereignty, 2018: p. 90-108.

[68] Rahadian, L., Menanti Revisi UU Migas demi Revitalisasi Sektor Migas Indonesia, in bisnis.com. 2019. 
[69] KPK, C.w., Kajian Harmonisasi Undang-Undang Sumber Daya Alam dan Lingkungan Hidup 2019.

[70] Riyandi, S., Peningkatan kualitas SDM buat Indonesia tidak jadi negara kuli, in Merdeka.com. 2013.

[71] Ministry of Industry, Hilirisasi Industri SDA Jadi Keharusan. 2019.

[72] Kosasih, F.U. Rich in Natural Resource: Blessed or Cursed? 2016.

[73] Ferraro, V. Dependency Theory: An Introduction 1996; Available from:

https://pdfs.semanticscholar.org/d715/82f1a87a914036b3af3696b2be 5e8411a7c8.pdf.

[74] Humphreys, D., The mining industry after the boom. Mineral Economics, 2019. 32(2): p. 145-151.

[75] Aziz, A., Menimbang Relaksasi Ekspor Nikel, in tirto.id. 2016.

[76] Thomas, V.F., Larangan Ekspor Bijih Nikel Amanat UU, Enggar Tak Perlu Keberatan, in tirto.id. 2019.
[77] Syafina, D.C., Percepatan Moratorium Ekspor Nikel, Sebuah Keharusan?, in tirto.id. 2019.

[78] Hayat, A., FDI and economic growth: the role of natural resources? Journal of Economic Studies, 2018. 45(2): p. 283-295.

[79] Moran, T.H. Is FDI in natural resources a "curse"? World trade report 2010 2010; Available from: https://www.wto.org/english/res_e/publications_e/wtr10_forum_e/wt r10_moran_e.htm.

[80] Kinoshita, Y. and N.F. Campos, Why does FDI go where it goes? New evidence from the transition economies. 2003: International Monetary Fund.

[81] Kolstad, I. and A. Wiig, Better the Devil You Know? Chinese Foreign Direct Investment in Africa. Journal of African Business, 2011. 12(1): p. 31-50.

[82] Ministry of Finance, Perencanaan dan Penganggaran Keuangan Daerah. 2017. 